\title{
Physiological responses of four soybean varieties and their effect to the yield in several saturated soil culture modification
}

\author{
TOYIP ${ }^{1,2}$, MUNIF GHULAMAHDI ${ }^{3, \vartheta}$, DIDY SOPANDIE ${ }^{3}$, SANDRA A. AZIZ ${ }^{3}$, ATANG SUTANDI ${ }^{4}$, \\ M. YANUAR J. PURWANTO \\ ${ }^{1}$ Graduate School of Institut Pertanian Bogor. Jl. Raya Dramaga, Bogor 16680, West Java, Indonesia \\ ${ }^{2}$ Program of Agrotechnology, Faculty of Agriculture, Universitas Sintuwu Maroso. Jl. Pulau Timor No.1, Poso 94612, Central Sulawesi, Indonesia \\ ${ }^{3}$ Department of Agronomy and Horticulture, Faculty of Agriculture, Institut Pertanian Bogor. J1. Meranti, Bogor 16680, West Java, Indonesia. \\ Tel.: +62-251-8629354, Fax.: +62-251-8629352, `email: mghulamahdi@yahoo.com, th.amazon36@ gmail.com \\ ${ }^{4}$ Department of Soil Sciences and Land Resources, Faculty of Agriculture, Institut Pertanian Bogor. Jl. Meranti, Bogor 16680, West Java, Indonesia \\ ${ }_{5}^{5}$ Department of Civil and Environmental Engineering, Faculty of Agricultural Technology, Institut Pertanian Bogor. Jl. Lingkar Akademik, Bogor 16680, \\ West Java, Indonesia
}

Manuscript received: 21 May 2019. Revision accepted: 23 July 2019

\begin{abstract}
Toyip, Ghulamahdi M, Sopandie D, Aziz SA, Sutandi A, Purwanto MYJ. 2019. Physiological responses of four soybean varieties and their effect to the yield in several saturated soil culture modification. Biodiversitas 20: 2266-2272. This study aimed to evaluate the production and physiological response of four soybean varieties in saturated soil culture (SSC), compared to conventional dry culture on tidal swamp soil growing media. Four popular varieties in Indonesia, namely Anjasmoro, Grobogan, Tanggamus and Malika, were planted on undisturbed intact tidal swamp soil from Jambi from November 2016 to March 2017 at Bogor. Randomized completely block design with two factors applied in this work, i.e. 4 varieties namely Anjasmoro, Grobogan, Tanggamus and Malika; and 9 culture methods such as dry culture as control of no SSC (i), 1 months SSC (ii), 1.5 months SSC (iii), 2 months SSC (iv), continuous SSC (v), 1 months SSC with water improvement (vi), 1.5 months SSC with water improvement (vii), 2 months SSC with water improvement (viii), and continuous SSC with water improvement (ix). The results showed that (i) pod production per plant was significantly affected by the interaction of both factors; (ii) different varieties lead to significant different of physiological response, i.e. photosynthetic rate, transpiration rate, stomatal conductance and water use efficiency; (iii) the variation of culture methods only showed a significant effect on photosynthetic rate, i.e. saturated soil culture with water improvement (SSC WI) showed $48 \%$ and $18 \%$ higher photosynthetic rate than dry culture and regular SSC methods, respectively. Pod production was positively correlated to photosynthetic rates and water use efficiency; and negatively correlated to transpiration and stomatal conductance. The highest number of pod production per plant was achieved by Malika variety that planted in 2 months SSC WI.
\end{abstract}

Keywords: Leaf stomatal conductance, photosynthetic rate, transpiration, water improvement, WUE

Abbreviations: DC: dry culture, SSC: saturated soil culture, SSC WI: saturated soil culture with water improvement, WUE: water use efficiency

\section{INTRODUCTION}

Soybean (Glycine max (L.) Merr) is one of commercial food crops commodity for Indonesian, along with rice and maize, due to its important role in various local food products. The demand for this commodity increases as the growth of population. The average of soybean demand in 2017 is 3.1 million tons. Most of the domestic demand was filled with importing soybean from out of the country. The contribution of domestic soybean production is only $30 \%$, while the rest is supported by the import activities (BPS 2017). There is a need to accelerate the domestic soybean production to impede the soybean import.

There are two main strategies to gain domestic soybean production, i.e intensification (giving additional input) and extensification (expanding production area). Tidal swamp is one of highly found marginal lands in Indonesia, i.e. \pm 20 million ha that potentially used as future soybean production area (Suwanda et al. 2014). Soybean cultivation in marginal land such as tidal swamp needs several adjustments through improvement of cultural practice. Saturated soil culture (SSC) was promoted as the appropriate technology to maintain the growth of soybean under various environmental stress on tidal swampland leading to the improvement of harvested yield (Ghulamahdi et al. 2010; Sagala et al. 2011). Saturated soil culture for soybean was applied by maintaining the water surface on the stable condition, i.e. $20 \mathrm{~cm}$ under soil surface (Ghulamahdi et al. 2009), so the detrimental effect of water excess (Troedson et al. 1983) and pyrite oxidation could be minimized (Sagala et al. 2011). The quality of water used in SSC system also influences the success of soybean production.

The water quality surrounding the tidal land is categorized as a low irrigation water quality (Anda et al. 2009) due to its high acidity (Imanudin dan Armanto 2012) caused by the excessive aluminum and iron content (Bhakty 2005; Noya et al. 2014). This low water quality could damage the soybean root leading to the decrease of soybean yield. To gain the soybean yield, there is a need to 
have water improvement. Previous studies reported the success of peaty mineral soil water ameliorant containing a humic acid to improve the yield of black soybean on tidal land (Pujiwati et al. 2015). However, there is an easier method to improve the water quality, i.e. neutralization. Additional input such as calcium oxide $\left(\mathrm{Ca}(\mathrm{OH})_{2}\right)$ and dolomite $\left(\mathrm{CaCO}_{3}\right)$ could be used as water neutralization agent (Nurisman et al. 2012). Alongside the development of water improvement through calcification, the period of saturated condition is also the key to the success of soybean production through SSC. The application of water improvement combined with either short or long-term SSC period would have various effects on soybean production depend upon the genotype

Several soybean genotypes were reported to have good adaptation under various environmental stress in tidal swampland (Spehar 1994; Spehar dan Galwey 1996; Kokubun 2013). Morphological adaptation under SSC was frequently reported. Some soybean genotypes were reported to show the increasing root length in low $\mathrm{pH}$ condition and the increasing root dry weight was reported to associate with the tolerance characters of soybean grown on acid soil with low pH stress (Kuswantoro 2017). Additionally, morphological adaptation in form of aerenchyma formation also used to enhance the internal diffusion of atmospheric and photosynthetic oxygen from the aerial parts to the flooded roots, allowing the roots to maintain the aerobic respiration (Jackson dan Colmer 2005; Yamauchi et al. 2013). Unfortunately, there are limited reports regarding how the soybean adapt its physiological performance under various saturated soil cultures. This study aimed to evaluate the physiological responses of four soybean varieties and their effect on the yield in several saturated soil culture methods.

\section{MATERIALS AND METHODS}

\section{Study area}

This study was conducted from November 2016 to March 2017 at Cikarawang experimental field of IPB University, Dramaga Sub-district, Bogor District, West Java Province, Indonesia.

\section{Procedures}

The experimental design used was a randomized completely block design with two factors. The first factor was four soybean varieties, namely Anjasmoro, Grobogan, Tanggamus, and Malika. The second factor was saturated soil culture (SSC) method that consisted of nine methods, i.e. dry culture as control of no SSC (i), 1 months SSC (ii), 1.5 months SSC (iii), 2 months SSC (iv), continuous SSC (v), 1 months SSC with water improvement (vi), 1.5 months SSC with water improvement (vii), 2 months SSC with water improvement (viii), and continuous SSC with water improvement (ix). There were 36 combination treatments and every treatment was repeated 5 times, so there were 180 experimental units.

This study was carried out inside a screen house with a size of $5 \mathrm{~m} \times 10 \mathrm{~m} \times 2 \mathrm{~m}$. The roof of the house was made from plastic to cover the plant inside from the rainfall. Growing medium in form of undisturbed intact tidal swamp soil, with a size of $0.2 \mathrm{~m} \times 0.2 \mathrm{~m} \times 0.4 \mathrm{~m}$ for every experimental unit, was collected from Simpang Village, Berbak Subdistrict, District of Tanjung Jabung Timur, Jambi Province, Indonesia. To ease the culture practices and prevent the damage to the growing medium, the soil was covered by polybags. There were two seeds planted on every polybag. Prior to planting, the seed was enriched with $5 \mathrm{~g} \mathrm{~kg}^{-1}$ Rhizobium sp. inoculants. Seed was replanted no later than 1 week after planting (WAP) to ensure that all of the seedlings were growing well. Weeding was conducted twice, i.e. 3 WAP and 6 WAP. For the dry culture (no SSC), the growing medium was maintained on $100 \%$ field capacity at 1-2 WAP, $80 \%$ field capacity at 3-4 WAP, $60 \%$ field capacity at 5-6 WAP and $40 \%$ field capacity at 7 WAP and so on. For the saturated soil culture, the water depth was daily maintained at $15 \mathrm{~cm}$ below the soil surface. The maintenance period of saturated soil condition was adjusted according to the treatments. For example, 1 month SSC means that the SSC would be applied in the first month after planting date and the rest would be held in dry culture method with manual watering. Untreated tidal swampy water (with $\mathrm{pH}$ around 2.2) collected from Simpang Village, Berbak Subdistrict was used for irrigation in no water improvement SSC. Water improvement was executed by calcium oxide application at the dosage of $1 \mathrm{~g} \mathrm{l}^{-1}$. Calcium oxide has to be well diluted into the irrigation tank prior to its distribution to the plant. The $\mathrm{pH}$ of improved irrigation water was higher than untreated water, i.e. 4.8. Pest, such as seed flies, pod borer and pod suckers, was controlled. The soybean was ready to be harvested when the green leaves turned to yellow. The harvested plant was detached from the growing medium and then sun-dried for two days. The observation was made both on physiological or production report. The observation was made on physiological responses and plant production. Physiological responses in term of photosynthetic rate, transpiration rate, stomatal conductance, and water use efficiency were measured by Li-6400XT portable photosynthesis system (Licor Inc, USA) at 9 WAP (Weeks After Planting). Pod production per plant was determined at the harvesting at 95 days after planting.

\section{Data analysis}

The collected data were processed by analysis of variance (ANOVA) by using SAS version 9.4. Any significant differences between treatments were tested by Duncan Multiple Range Test (DMRT) at a level of confident 5\% (Gomez and Gomez 1984; Mattjik and Sumertajaya 2006). The physiological characters and plant production were further evaluated with correlation and regression analysis. 
Table 1. Analysis of variance of plant production and physiological response of four soybean varieties under various saturated soil culture methods

\begin{tabular}{|c|c|c|c|c|}
\hline Variables & Varieties & Culture method & Interaction & CV \\
\hline Plant production & $* *$ & $* *$ & $* *$ & 3.95 \\
\hline Photosynthetic rate & $* *$ & $* *$ & $\mathrm{~ns}$ & 13.07 \\
\hline Transpiration rate & $* *$ & ns & ns & 17.14 \\
\hline Stomatal conductivity & $* *$ & $\mathrm{~ns}$ & $\mathrm{~ns}$ & 17.78 \\
\hline Water use efficiency & $* *$ & ns & ns & 32.15 \\
\hline
\end{tabular}

Note: CV: coefficient of variance; ns: not significantly different; **: significantly different

\section{RESULTS AND DISCUSSION}

Analysis of variance showed an interaction of varieties and culture methods that significantly affected the soybean production, however, there was no significant effect of this interaction on physiological characters, such as photosynthesis rates, transpiration rate, stomatal conductance and water use efficiency (Table 1). The effect of individual factor such soybean varieties gave a significant effect on all observed variables, while the culture methods only gave a significant effect on the rate of photosynthesis and crop production. The differences in soybean varieties showed a significant variation in term of photosynthetic rate (Figure 1). Grobogan showed the highest photosynthetic rate, while the Malika had the lowest one. The photosynthetic rate difference of the two varieties reached $2.28 \mu \mathrm{mol}$ of $\mathrm{CO}_{2} \quad \mathrm{~m}^{-2} \mathrm{~s}^{-1}$. The photosynthetic rate of Anjasmoro and Tanggamus varieties were not significantly different. The high photosynthetic rate of Grobogan may lead to the good and wide adaptability in various culture methods, ranging from dry culture up to soil saturated culture with improved water. High photosynthetic rate is an important physiological character because it is associated with faster carbohydrate accumulation for the process of recovery after stress exposure (Marschner 1995; Taiz and Zeiger 2002; Hao et al. 2014 and Mutava et al. 2014). Furthermore, photosynthetic rate of soybean positively related to the yield (Liu et al. 2008). Under optimum condition, without limitation of nutrients and biotic stress growth rate determined by photosynthetic material and plant photosynthetic capability (Grassini et al. 2014). Based on the description of Grobogan variety that has large seeds and early mature for about 76 days, is thought related to the high photosynthetic rate of that variety (Susanto and Nugrahaeni 2017). Photosynthetic rate increase assimilates accumulation into the seed. Soybean pod was a strong sink organ during the enlargement period. The assimilates were highly transferred to the strong sink organ. The higher assimilates produced for subsequent growth of soybean. The greater number of assimilates used to support the pod enlargement so the pod was early mature and have a large size. Previous study by Liu et al. (2012) showed the decrease days of maturity during 82 years soybean breeding program and increase of the yield was positively correlated with photosynthetic rate (Pn), so Pn could be used as the effective selection indexes.
The transpiration rate also showed a significant difference caused by different soybean varieties (Figure 2). The transpiration rate of Tanggamus was the highest one and significantly different from the rest. Tanggamus had $15 \%$ higher transpiration rate or equivalent to $0.015 \mathrm{mmol}$ $\mathrm{H}_{2} \mathrm{O} \mathrm{m}^{-2} \mathrm{~s}^{-1}$ compared to Grobogan. The transpiration rate of Grobogan, Anjasmoro, and Malika was not significantly different from one another. Our finding was in agreement with the previous study that reported the variation of soybean varieties to show different transpiration rate (Bunce 2016). Plant transpiration is also related to stomatal conductivity. The decline of transpiration per leaf area is caused by the decline of stomatal conductivity. Forty percent of stomatal conductance reduction lead to $10 \%$ reduction of canopy water content (Sopandie 2013). In addition, plant transpiration is also related to the time of observation. Plants generally experience an increase in transpiration during the day which causes a temporary water deficit and subsequently causes interference with some physiological processes (Wahid et al. 2007). The increasing transpiration rate is only temporary due to the high temperatures exposure in the hot midday. The ability to maintain the transpiration rate, along with adjusting the carbon assimilation, would determine the final yield of soybean (Sloane et al. 1990).

Different varieties also show significant variations in stomatal conductance response (Figure 3). This finding was in line with Gilbert et al. (2011) and Bunce (2016). Stomatal conductance showed a similar pattern with the transpiration rate. Tanggamus has the highest stomatal conductance and it was significantly different to Grobogan and Anjasmoro, while Malika has not differed to the rest varieties (Tabel 3). Stomatal conductance affects the gas exchange activities and water balance in the plant's body. Low stomatal conductance is commonly found in plants that are gripped by osmotic stress, for example, drought stress (Makbul et al. 2011; Hossain et al. 2015). The stress forced the plants to close most of their stomata to avoid water shortage and keep the balance of water in the plant's body (Davies and Zhang 1991). Stomatal conductance correlated to limitation of photosynthetic capacity in plants trough three processes, are restricted diffusion of carbon dioxide $\left(\mathrm{CO}_{2}\right)$ through stomata (Ls) and through the internal conductance in mesophyll (Lm) or photobiochemical mechanisms (Lb) (Singh dan Reddy 2016). Stomatal conductance is reported to vary depending on the times, i.e relatively low in the morning (early morning), then gradually increase until noon and are stable until the 
afternoon, then begin to decline after 16.30 while in soybean responses of stomatal closure and opening could described by sigmoid function and affected by appearance of light (Mencuccini et al. 2000; Liu et al. 2003; Grantz et al. 2019). Furthermore, Grantz dan Zeiger (1986) explained that stomatal movement was induced by light whereas are the result of transduction of the light stimulate modulates ion fluxes in guard cells and concomitant osmotic adjustment and turgor changes. In this study, stomatal conductivity was measured at relatively the same time at 9:00, so that it could eliminate the effect of differences in stomatal conductance due to differences in measurement time.

Similar to previous variables, water use efficiency (WUE) is also influenced by variety of types (Figure 4). Previous research by Gilbert et al. (2011) and Bunce (2016) reported a significant difference in WUE between soybean varieties. Grobogan is the most efficient variety while Tanggamus is the most inefficient one. The difference in water use efficiency of the two varieties is $0.003 \%$. WUE of Grobogan and Anjasmoro was not significantly different, similar to the case between Tanggamus and Malika. WUE improvement is one of plant adaptation

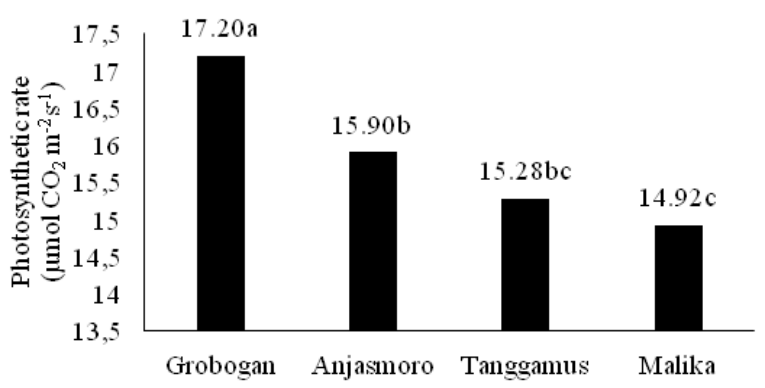

Figure 1. The mean values of photosynthetic rate of four soybean varieties on saturated soil culture modified system. Note: values followed by the same letter inside the bar chart were not significantly different in DMRT at $\alpha$ 5\%.

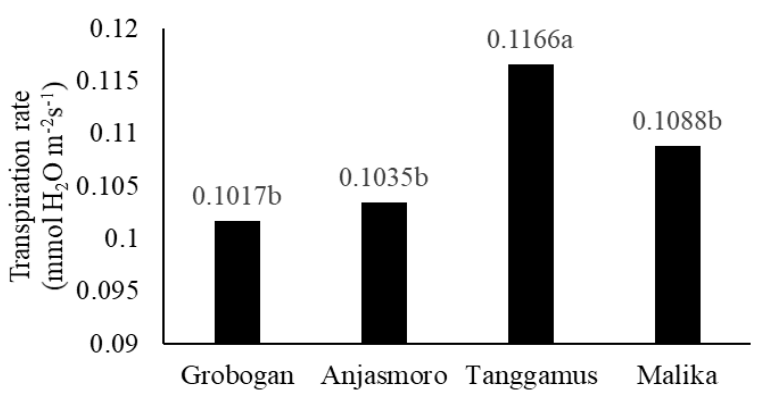

Figure 2. The mean values of transpiration rate of four soybean varieties. Note: values followed by the same letter inside the bar chart were not significantly different in DMRT at $\alpha 5 \%$. strategy to handle abiotic stresses, such as drought stress (Bunce 2016). Soybean varieties that have a high WUE generally have a high resistance to drought stress (Hossain et al. 2015).

Unlike the variety factor, the variation of culture methods only showed a significant effect on the photosynthetic rate of soybean (Figure 5), while the rest observed variables seemed to be unaffected significantly (Table 2). Soybean grown in dry culture showed the lowest photosynthetic rate, while the best result showed in saturated soil culture with water improvement (SSC WI) method. Soybean planted in SSC WI method possessed the greater photosynthetic rates by $48 \%$ compared to dry cultivation, and $18 \%$ compared to general SSC without water improvement. There is a tendency that the longer the saturated period in the SSC method, the higher the photosynthetic rate of the soybean. The highest photosynthetic rate was observed in the 2 months SSC WI method, i.e $17.95 \mu \mathrm{mol} \mathrm{CO} \mathrm{Cm}^{-2} \mathrm{~s}^{-1}$, while the lowest value was found in the dry cultivation, i.e. $11.75 \mu \mathrm{mol} \mathrm{CO}_{2} \mathrm{~m}^{-2} \mathrm{~s}$ ${ }^{1}$, with the difference of both treatments was $5.83 \mu \mathrm{mol}$ $\mathrm{CO}_{2} \mathrm{~m}^{-2} \mathrm{~s}^{-1}$

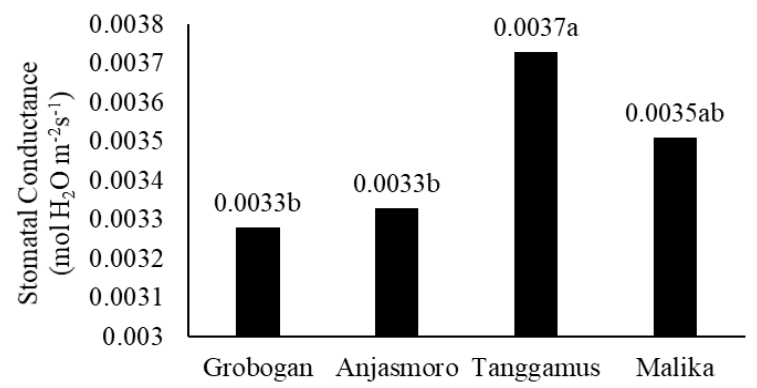

Figure 3. The mean values of stomatal conductance of four soybean varieties. Note: values followed by the same letter inside the bar chart were not significantly different in DMRT at $\alpha 5 \%$.

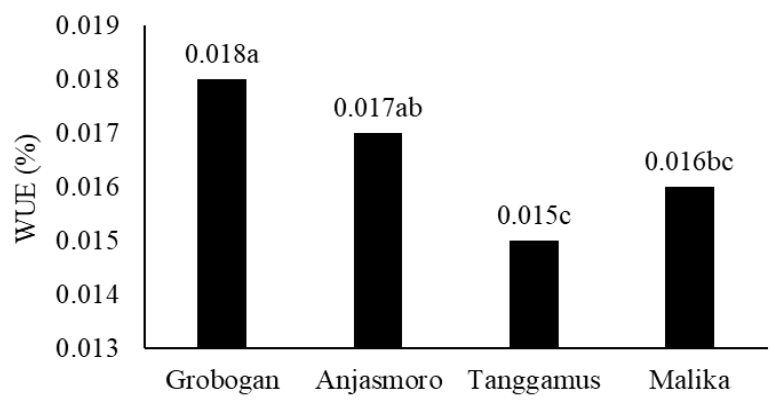

Figure 4. The mean values of water use efficiency of four soybean varieties. Note: values followed by the same letter inside the bar chart were not significantly different in DMRT at $\alpha 5 \%$.

Table 3. Chemical qualities of irrigation water used in saturated soil cultures

\begin{tabular}{|c|c|c|c|c|c|c|c|c|}
\hline \multirow[t]{2}{*}{ Irrigation water } & DHL $2^{\circ} \mathrm{C}$ & pH & $\mathbf{C a}$ & $\mathbf{F e}$ & Al & $\mathrm{PO}_{4}$ & $\mathrm{SO}_{4}$ & $\mathrm{NO}_{3}$ \\
\hline & ds $m^{-1}$ & & \multicolumn{6}{|c|}{$\mathrm{mgl}^{-1}$} \\
\hline Without water improvement & 5.89 & 2.2 & 77.59 & 230.05 & 36.97 & 0.03 & 4988.51 & 6.25 \\
\hline With water improvement & 4.56 & 4.8 & 117.22 & 0.03 & 0 & 8.33 & 3576.1 & 107.76 \\
\hline
\end{tabular}


Table 2. Physiological responses of several planting methods

\begin{tabular}{|c|c|c|c|c|c|c|c|c|c|}
\hline \multirow{2}{*}{ Variables } & \multirow{2}{*}{ DC } & \multicolumn{4}{|c|}{ Duration of SSC (months) } & \multicolumn{4}{|c|}{ Duration of SSC WI (months) } \\
\hline & & $\mathbf{1}$ & 1.5 & 2 & $\mathbf{C}$ & 1 & 1.5 & 2 & $\mathbf{C}$ \\
\hline Transpiration rate & 0.1112 & 0.1136 & 0.1070 & 0.1079 & 0.1105 & 0.1064 & 0.1049 & 0.1057 & 0.1028 \\
\hline Stomatal conductivity & 0.0035 & 0.0036 & 0.0034 & 0.0035 & 0.0036 & 0.0034 & 0.0034 & 0.0034 & 0.0033 \\
\hline Water use efficiency & 0.0139 & 0.0149 & 0.0173 & 0.0160 & 0.0155 & 0.0171 & 0.0167 & 0.0165 & 0.0170 \\
\hline
\end{tabular}

Note: DC: dry culture, SSC: saturated soil culture, SSC WI: saturated soil culture with water improvement, C: continuous saturated soil culture.

Table 4. Correlation analysis of physiological response and production of four soybean varieties under various saturated soil culture methods

\begin{tabular}{lcccc}
\hline & Photosynthetic rate & Transpiration rate & Stomatal conductance & Water use efficiency \\
\hline Transpiration rate & -0.4771 & & & \\
Stomatal conductance & -0.4529 & 0.994 & -0.7443 & 0.1000 \\
Water use efficiency & 0.5843 & -0.7447 & -0.0364 & \\
Pod production & 0.4531 & -0.0638 & & \\
\hline
\end{tabular}

Table 5. Pod production per plant of four soybean varieties under various saturated soil culture methods

\begin{tabular}{|c|c|c|c|c|c|c|c|c|c|}
\hline \multirow{3}{*}{ Varieties } & \multirow{3}{*}{ DC } & \multicolumn{8}{|c|}{ Pod production per plant } \\
\hline & & \multicolumn{4}{|c|}{ Duration of SSC (months) } & \multicolumn{4}{|c|}{ Duration of SSC WI (months) } \\
\hline & & 1 & 1.5 & 2 & $\mathbf{C}$ & 1 & 1.5 & 2 & $\mathbf{C}$ \\
\hline Grobogan & 80 & $21.6 \mathrm{lmn}$ & $28.3 \mathrm{jk}$ & $36.3 \mathrm{~g}$ & $43.6 \mathrm{ef}$ & $30.3 \mathrm{ij}$ & $49 \mathrm{~d}$ & $64 \mathrm{~b}$ & $56.3 \mathrm{c}$ \\
\hline Anjasmoro & $3 \mathrm{p}$ & $19 \mathrm{n}$ & $23.3 \mathrm{~lm}$ & $28.3 \mathrm{jk}$ & $31.6 \mathrm{hij}$ & $30.3 \mathrm{ij}$ & $47.6 \mathrm{~d}$ & $63 \mathrm{~b}$ & $41 \mathrm{f}$ \\
\hline Tanggamus & 5 op & $21.6 \mathrm{lmn}$ & 34 hgi & $45.3 \mathrm{ed}$ & $24.3 \mathrm{~lm}$ & $20.6 \mathrm{mn}$ & $35.6 \mathrm{~g}$ & $48.3 \mathrm{~d}$ & $37.3 \mathrm{~g}$ \\
\hline Malika & $5.6 o p$ & $25 \mathrm{kl}$ & $47.6 \mathrm{~d}$ & $53.6 \mathrm{c}$ & $55 \mathrm{c}$ & $35 \mathrm{gh}$ & $36 \mathrm{~g}$ & $72.3 \mathrm{a}$ & $64 \mathrm{~b}$ \\
\hline
\end{tabular}

Note: values in column followed by different alphabet are significantly different based on DMRT at $\alpha$ 5\%, DC: dry culture, SSC: saturated soil culture, SSC WI: saturated soil culture with water improvement, C: continuous saturated soil culture.

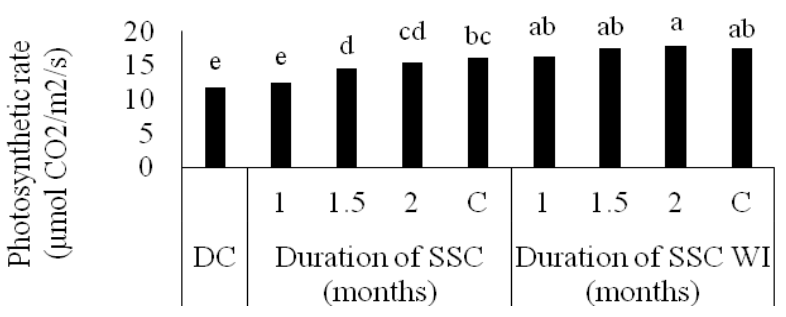

Figure 5. The mean values of soybean photosynthetic rate under various saturated soil culture methods. Note: values followed by the same letter inside the bar chart were not significantly different in DMRT at $\alpha 5 \%$. DC: dry culture, SSC: saturated soil culture, SSC WI: saturated soil culture with water improvement, C: continuous saturated soil culture

Low photosynthetic rates in soybeans planted under dry culture methods are thought to be associated with several abiotic stresses such as (i) drought stress caused by the low water availability; and (ii) pyrite oxidation caused by the use of acid sulfate soil as a growing medium. The lack of water could impede the plant growth because water has so many functions for photosynthesis, nutrient and plant assimilates distribution. The decline of photosynthesis in drought-stressed the plant is associated with the stomata restriction (Wang et al. 2018) lead to the limitation of carbon assimilation and finally reduce soybean pod production (Stolf et al. 2009).

In term of tidal land management, the presence of adequate water could help the reduction of pyrite $\left(\mathrm{FeS}_{2}\right)$ oxidation that threatened the soybean growth. Pyrite oxidation is a chemical process in the soil layer that induced by excessive soil tillage, soil cracks or excessive drainage (Sopandie 2013) that can increase soil acidity and solubility of toxic compounds such as $\mathrm{Al}^{3+}$ and $\mathrm{Fe}^{2+}$ (Noya et al. 2014) resulting in nutrient deficiency and also the decline of photosynthetic rate of cultivated plants (Taiz and Zeiger 2002; Proklamasiningsih et al. 2012; Sopandie 2013). The maintenance of water level through SSC method able to suppress the occurrence of pyrite oxidation (Sagala et al. 2011). Water improvement on SSC method has succeeded to improve plant photosynthesis compared to regular SSC methods. Calcium oxide application produced a more neutral $\mathrm{pH}$ irrigation water with lower $\mathrm{Fe}$ and $\mathrm{Al}$ solubility (Table 3 ).

Based on correlation analysis, soybean photosynthetic rate was negatively correlated to transpiration and stomatal conductance, but it was positively correlated to water use efficiency and pod production per plant (Table 4). The transpiration rate had a positive and strong correlation to stomatal conductance $(\mathrm{r}=0.994)$. It was likely that soybean varieties with a low transpiration rate are supposed to have low stomatal conductance, and vice versa. The WUE is 
negatively and strongly correlated $(r=0.744)$ to the transpiration rate and also stomatal conductance, means that soybean with high transpiration and stomata conductance level are generally less efficient in term of water use. This finding is in agreement with the previous researcher that state the WUE was not correlated significantly $(\mathrm{r}=0.047)$ to mesophyll conductance, but it was negatively correlated with stomatal conductance and canopy transpiration (Bunce 2016).

The pod production of soybean is also positively correlated to photosynthetic rates and WUE (Table 4). Soybean plants that have high photosynthetic rates and efficient in term of water use are thought to have greater yields, and vice versa. Soybean pod production was influenced by interactions of both factors, i.e varieties and culture methods. All varieties grown on dry culture methods have the lowest production and they are significantly different compared to other culture methods (Table 5). Dry culture in soil growing media that obtained from tidal land inhibits plant growth with 2 types of stresses, namely drought stress and pyrite oxidation. Previous research also reported the decline of yields on acid growing media, with a $\mathrm{pH}$ value below 5 (Uguru et al. 2012; Adie and Krisnawati 2016).

On the other hand, the SSC WI for 2 months is the most successful method to gain the soybean pod production on tidal soil. The difference in pod production of each variety between those planted with dry culture compared to the SSC WI for 2 months is varied depending upon the soybean variety, i.e. 56 pods for Grobogan, 60 pods for Anjasmoro, 43 pods for Tanggamus and 66 pods for Malika. The highest number of pod production was found in Malika variety that planted in 2 months SSC WI, i.e. 72 pods per plant (Tabel 5).

In conclusion, the pod production was significantly affected by the interaction of soybean varieties and culture methods, with the best result showed by Malika that planted in the SSC WI for 2 months. In general, the SSC WI for 2 months is the best method to gain the soybean pod production on tidal soil. Culture methods variation lead to a significant effect on the photosynthetic rate, i.e. SSC WI showed $48 \%$ and $18 \%$ greater rate than dry culture and regular SSC methods, respectively. Different soybean varieties showed a significant difference of physiological responses, i.e. photosynthetic rate, transpiration rate, stomatal conductance, and water use efficiency. Pod production per plant was positively correlated to photosynthetic rates and WUE; and negatively correlated to transpiration and stomatal conductance.

\section{ACKNOWLEDGEMENTS}

This study was supported by Ministry of Research and Higher Education, Republic of Indonesia through Doctoral Grant financial year 2018 no. 3/E/KPT2018 and 022/lppmusm/lit/v/2018. There are no conflicts of interest resulted from this study.

\section{REFERENCES}

Adie MM, Krisnawati A. 2016. Identification of soybean genotypes adaptive and productive to acid soil agro-ecosystem. Biodiversitas 17: 565-570. [Indonesian]

Anda M, Siswanto AB, Subandiono RE. 2009. Properties of organic and acid sulfate soils and water of a 'reclaimed' tidal backswamp in Central Kalimantan, Indonesia. Geoderma 149: 54-65. [Indonesian]

Bhakty TE. 2005. Pengaruh kualitas air terhadap kualitas tanah pada tata saluran irigasi pasang surut di Kabupaten Barito Kuala, Kalimantan Selatan. J Keairan 12: 1-14. [Indonesian]

BPS. 2017. Kajian konsumsi bahan pokok tahun 2017 katalog BPS: 8299003. http://www.bps.go.id/site /resultTab. [Indonesian]

Bunce J. 2016. Variation among soybean cultivars in mesophyll conductance and leaf water use efficiency. Plants 5: 1-9.

Davies WJ, Zhang J. 1991. Root signals and the regulation of growth and development of plants in drying soil. Ann Rev Plant Physiol Plant Mol Biol 42: 55-76.

Ghulamahdi M, Aziz SA, Makarim AK. 2010. Penerapan teknologi budidaya jenuh air pada tanaman padi dan kedelai untuk meningkatkan indeks penanaman di lahan pasang surut. In: Mendukung kedaulatan pangan dan energi yang berkelanjutan. Simposium dan seminar bersama PERAGI-PERHORTI-PERIPIHIGI hlm. 978-979. [Indonesian]

Ghulamahdi M, Melati M, Sagala D. 2009. Production of soybean varieties under saturated soil culture on tidal swamps. J Agron Indones 37: 226-232. [Indonesian]

Gilbert ME, Zwieniecki MA, Holbrook NM. 2011. Independent variation in photosynthetic capacity and stomatal conductance leads to differences in intrinsic water use efficiency in 11 soybean genotypes before and during mild drought. J Exp Bot 62: 2875-2887.

Gomez KA, Gomez AA. 1984. Statistical procedures for agricultural research (2 edition). John Wiley and Sons. New York.

Grantz DA, Linscheid BS, Grulke NE. 2019. Differential responses of stomatal kinetics and steady state conductance to abscisic acid in a fern: comparison with a gymnosperm and an angiosperm. New Phytol Trust 1 (September 2018) 1-24. DOI:10.1111/nph.15736.

Grantz DA, Zeiger E. 1986. Stomatal responses to light and leaf-air water vapor pressure difference show similar kinetics in sugarcane and soybean. Plant Physiol 81: 865-868.

Grassini P, Torrion JA, Cassman KG, Yang HS, Specht JE. 2014. Drivers of spatial and temporal variation in soybean yield and irrigation requirements in the western US Corn Belt. F Crop Res 163 32-46.

Hao X, Gao J, Han X, Ma Z, Merchant A, Ju H, Li P, Yang W, Gao Z, Lin E. 2014. Effects of open-air elevated atmospheric $\mathrm{CO}_{2}$ concentration on yield quality of soybean (Glycine max (L. Merr). Agricult Ecosyst Environ 192 80-84.

Hossain MM, Lam HM, Zhang J. 2015. Responses in gas exchange and water status between drought-tolerant and susceptible soybean genotypes with ABA application. Crop J 3: 500-506.

Imanudin MS, Armanto E. 2012. Effect of water management improvement on soil nutrient content, iron and aluminum solubility at tidal low land area. $2^{\text {nd }}$ International Conference on Asia Agricultura. APCBEE Procedia, Singapore.

Jackson MB, Colmer TD. 2005. Response and adaptation by plants to flooding stress. Ann Bot 96: 501-505.

Kokubun M. 2013. Genetic and cultural improvement of soybean for waterlogged conditions in Asia. Field Crop Res 152: 3-7

Kuswantoro H. 2017. Genetic variability and heritability of acid-adaptive soybean promising lines. Biodiversitas 18: 378-382. [Indonesian]

Liu G, Yang C, Xu K, Zhang Z, Li D, Wu Z, Chen Z. 2012. Development of yield and some photosynthetic characteristics during 82 years of genetic improvement of soybean genotypes in Northeast China [online]. Aust J Crop Sci 6: 1416-1422.

Liu F, Jensen CR, Andersen MN. 2003. Hydraulic and chemical signals in the control of leaf expansion and stomatal conductance in soybean exposed to drought stress. CSIRO Publ. 30: 65-73.

Liu X, Jin J, Wang G, Herbert SJ. 2008. Soybean yield physiology and development of high-yielding practices in Northeast China. F Crop Res 105: 157-171.

Makbul S, Guler NS, Durmus N, Guven S. 2011. Changes in anatomical and physiological parameters of soybean under drought stress. Turk J Bot 35: 369-377.

Marschner H. 1995. Mineral Nutrition of Higher Plants. Academic Press. New York. 
Mattjik AA, Sumertajaya IM. 2013. Perancangan Percobaan dengan Aplikasi SAS dan Minitab. IPB Press, Bogor. [Indonesian]

Mencuccini M, Mambelli S, Comstock J. 2000. Stomatal responsiveness to leaf water status in common bean (Phaseolus vulgaris L.) is a function of time of day. Plant Cell Environ 23: 1109-1118.

Mutava RN, Jebakumar S, Prince K, Hasan N, Song L, Valliyodan B, Chen W, Nguyen HT. 2014. Plant physiology and biochemistry understanding abiotic stress tolerance mechanisms in soybean: A comparative evaluation of soybean response to drought and flooding stress. Plant Physiol Biochem (November) 1-12. DOI:10.1016/j.plaphy.2014.11.010

Noya AI, Ghulamahdi M, Sopandie D, Sutandi A, Melati M. 2014 Interactive effects of aluminum and iron on several soybean genotypes grown in nutrient solution. Asian J Plant Sci 13: 18-25.

Nurisman E, Cahyadi R, Hadriansyah I. 2012. Studi terhadap dosis penggunaan kapur tohor $(\mathrm{CaO})$ pada proses pengolahan air asam tambang pada kolam pengendap lumpur tambang air laya PT Bukit: Asam (Persero), Tbk. J Teknik Patra Akademik 5: 8-12. [Indonesian]

Proklamasiningsih E, Prijambada ID, Rachmawati D, Sancayaningsih RP. 2012. Laju fotosintesis dan kandungan klorofil kedelai pada media tanam masam dengan pemberian garam aluminium. Agrotrop 2: 17 24. [Indonesian]

Pujiwati H, Ghulamahdi M, Yahya S, Aziz SA, Haridjaja O. 2015. The application of peaty mineral soil water in improving the adaptability of black soybean toward aluminum stress on tidal mineral soil with saturated water culture. Agrivita 37: 284-289.

Sagala D, Ghulamahdi M, Melati M. 2011. Pola serapan hara dan pertumbuhan beberapa varietas kedelai dengan budidaya jenuh air di lahan rawa pasang surut. J Agroqua 9: 1-10. [Indonesian]

Singh SK, Reddy VR. 2016. Methods of mesophyll conductance estimation: Its impact on key biochemical parameters and photosynthetic limitations in phosphorus-stressed soybean across $\mathrm{CO}_{2}$. Physiol Plant 157: 234-254.

Sloane RJ, Patterson RP, Carter TR Jr. 1990. Field drought tolerance of a soybean plant introduction. Crop Sci 30: 118-123.

Stolf R, Medri ME, Pimenta JA, Boeger MRT, Dias J, Lemos NG, Oliveira MCND, Brogin RL, Yamanaka N, Neumaier N, Farias JRB,
Nepomuceno AL 2009. Morpho-anatomical and micromorphometrical evaluations in soybean genotypes during water stress. Braz Arch Biol Technol 52: 1313-1331.

Spehar CR. 1994. Field screening of soya bean (Glycine max (L.) Merrill) germplasm for aluminum tolerance by the use of augmented design. Euphytica 76: 203-213.

Spehar CR, Galwey NW. 1996. Diallel analysis for aluminum tolerance in tropical soybeans (Glycine $\max (\mathrm{L}$.) Merrill). Theor Appl Genet 92: 267-272.

Susanto GWA, Nugrahaeni N. 2017. Pengenalan dan karakteristik varietas unggul kedelai. http://balitkabi.litbang.pertanian.go.id/wpcontent/uploads/2018/03/bunga_rampai_2017_2_gatut.pdf [Indonesian]

Suwanda H, Noor M, Badan P, Pertanian L, Litbang B, Lahan S, Tentara J, No P. 2014. Kebijakan pemanfaatan lahan rawa pasang surut untuk mendukung kedaulatan pangan nasional. J Sumberdaya Lahan 8: 3140. [Indonesian]

Sopandie D. 2013. Fisiologi Adaptasi Tanaman terhadap Cekaman Abiotik pada Agroekosistem Tropika. IPB Press, Bogor. [Indonesian]

Taiz L, Zeiger E. 2002. Plant Physiology. Sinauer Associates Inc Publishers. California

Troedson RJ, Lawn B, Byth DBGL. 1983. Saturates soil culture an innovative water management option for soybean in the tropics and subtropics. In: Shanmugasundaram S, Sulzberger EW, Mc Lean BT (eds) Soybean in tropical and subtropical cropping systems. Proc Symp Tsukuba. Japan, 26 September-10 October 1983.

Uguru MI, Oyiga BC, Jandong EA. 2012. Responses of some soybean genotypes to different soil $\mathrm{pH}$ regimes in two planting seasons. Afr $\mathrm{J}$ Plant Sci Biotechnol 6: 26-37.

Wahid A, Gelani S, Ashraf M, Foolad MR. 2007. Heat tolerance in plants: An overview. Env Exp Bot 61: 199-223.

Wang W, Wang C, Pan D, Zhang Y, Luo B, Ji J. 2018. Effects of drought stress on photosynthesis and chlorophyll fluorescence images of soybean (Glycine max) seedlings. Int J Agric Biol Eng 11: 196-201.

Yamauchi T, Shimamura S, Nakazono M, Mochizuki T. 2013. Aerenchyma formation in crop species: A review. Field Crop Res 152: 8-16. 